14 Gautel M, Lakey A, Barlow DP, et al. Titin antibodies in myasthenia gravis: Identification of a major autogenic region of titin. Neurology 1994 (in press).

15 Grob D, Arsura EL, Brunner NG, Namba T. The course of myasthenia gravis and therapies affecting outcome. Ann NY Acad Sci 1987;505:472-99.

16 Oosterhuis HJGH. The natural course of mysthenia gravis: a long term follow up study. $\mathcal{F}$ Neurol Neurosurg Psychiatry 1989;52:1121-7.

17 Durelli L, Maggi G, Casadio C, Ferri R, Rendine S, Bergamini $L$. Actuarial analysis of the occurrence of remissions following thymectomy for myasthenia gravis in 400 patients. $\mathcal{F}$ Neurol Neurosurg Psychiatry 1994;54: in 400 -11.
18 Mantegazza R, Beghi E, Pareyson D, et al. A multicentre follow up study of 1152 patients with myasthenia gravis in Italy. $\Im$ Neurol 1990;237:339-44.

19 Pagala MKD, Nandakumar NV, Venkatachari SAT, Ravindran K, Namba T, Grob D. Responses of intercostal muscle biopsies from normal subjects and patients with myasthenia gravis. Muscle Nerve 1990;13: 1012-22.

20 Nielson VK, Paulson OB, Rosenkvist J, Holsøe E, Lefvert AK. Rapid improvement of myasthenia gravis after AK. Rapid improvement of myasthenia grav

21 Namba T, Brunner NG, Grob D. Idiopathic giant cell polymyositis: report of a case and review of the synpolymyositis: report of a case and
drome. Arch Neurol 1974;31:27-30.

\section{Jean Lhermitte 1877-1959}

Jean L Lhermitte, son of an artist, was born at MonSaint-Père Aisne in 1877. After school at St Etienne he studied medicine in Paris, graduating in 1907. He immediately turned to neurology for both clinical training and research. Over many years he was associated with Gustave Roussy in texts on Blessures de la moëlle et de la queue de cheval, published in 1918, and on treatment of the neuroses of wartime: Traitement des psychonévroses de guerre, issued in 1919; and (with Spiller) on the internuclear ophthalmoplegia of epidemic encephalitis. Anterior internuclear ophthalmoplegia is often referred to as Lhermitte's syndrome.
He showed the importance of the inferior olivary nucleus in myoclonus.

His outstanding abilities led to his appointment as clinical director at the Salpêtrière Hospital, Paris where he became one of the greatest clinical neurologists of his day. His enthusiasm was seldom concealed and between the World Wars he inspired and led a generation of young neurologists.

A deeply religious man, he applied his scholarship to the interface of medicine and theology, including studies on stigmatisation and demoniacal possession.

Lhermitte died peacefully in 1959.

J M S PEARCE 304 Beverley Road,
Anlaby, Hull HU10 $7 B G$

\section{Lhermitte's sign}

Although more properly designated a symptom than a sign, the importance of this phenomenon was brought to the neurological world by Jean Lhermitte in $1924 .^{1}$ Mme D, was a cashier, 43 years old with no past or family history of note, when in July 1923:

a few days after ... an illness with abdominal pains and diarrhoea she suffered a rather violent headache accompanied by tingling in the feet and knees. At this time, walking became difficult . . .

In August 1923 the patient first noticed a phenomenon that she described thus: "When I try to lower my head, I feel a violent shock in the nape of my neck, and a pain like an electric shock runs through my whole body, from my neck to my feet, down my vertebral column" . . . each flexion movement of the head or the trunk brought on this sensation ... from the nape of the neck to the tips of the toes and also of the fingers. The patient could not dress herself, put on her shoes or pick up an object from the ground without carefully keeping her head in line with her trunk.

Until May 1924, the condition did not change . . . At this period a new and disturbing symptom appeared: marked impairment of vision of the right eye ....

We would like to direct attention to a particular manifestation that we believe has never been pointed out in the symptomatology of multiple sclerosis: the pains resembling an electric shock.... The sensations are uncomfortable but not really painful, and closely resemble those produced by faradic current. They never occur spontaneously... but occur exclusively with movements accompanied by forward flexion of the head.... These sensations are always rapid and brief, because by an instinctive reflex, the patient corrects the position...

It was described by Babinski and Dubois ${ }^{2}$ (Society of Neurology 1918) in concussions of the spine, and one of us (Lhermitte) published two observations regarding it, inserted in the excellent thesis of J Ribeton (Clinical study of pains resembling electrical shock following injuries to the neck. Thesis Univ Paris January 1919).

Lhermitte continues and emphasises two points:

the shock like pains in direct spinal concussion as in multiple sclerosis are related not to root changes but to spinal lesions....

Tinel accurately observed that tingling (we add the electrical sensations) produced by percussion or elongation requires that these nerves be composed of demyelinated fibres ... the type of pain presents the inherent excitability of sensory fibres stripped of their insulating myelin sheath. This excitability may be evoked by direct percussion, which one applies to a peripheral nerve, or by elongation brought about by flexion of the head on the trunk. J M S PEARCE
304 Beverley Road, Anlaby, Hull HU10 $7 B G$

1 Lhermitte J, Bollak A, Nicholas M. Les douleurs à type de décharge électrique consécutives à la flexion céphalique dans la sclérose en plaques. Un cas de forme sensitive de la sclérose multiple. Rev Neurol 1924;2:56-62.

2 Babinski J, Dubois A. Douleurs à forme de décharge électrique, consécutives aux traumatismes de la nuque. Presse Med 1918;26:64. 